\title{
THE METHODOLOGY OF THE ANALYSIS OF CASE STUDY THROUGH THE INTEGRATION OF THE ROMA MINORITY INTO THE SOCIAL SYSTEM
}

Dr. Jelena Maksimović, University of Niš, Faculty of Philosophy, E-mail: jelena.maksimovic@filfak.ni.ac.rs

MA Jelena Osmanović, University of Niš, Faculty of Philosophy, E-mail: osmanovic.jelena@gmail.com

ART ICLE INFO

Case Study

Received: March, 26. 2017.

Revised: May, 16.2017.

Accepted: May, 22.2017

doi:10.5937/IJCRSEE1701097M

UDK

$316.72(=214.58)$

$323.15(=214.58)$

\section{Keywords:}

case study,

methodological analysis,

national minority,

social system.

\section{A B S T R A C T}

The Roma are an ethnic group that is spread throughout the world. Although there are poor ethnographic and historical notes about the origin of Roma on the basis of a study of legends and oral traditions, researchers who are engaged in Roma studies, often confirm that they originate from India. Their culture, habits, customs were mostly transmitted through the living word, from generation to generation. This research analyzed case studies of integration of the Roma minority in the social system. Special emphasis in research is aimed at analyzing stereotypes that arise from cultural patterns of Roma, given the fact that for them there are many different prejudices, while on the other hand, there is no access with critical analysis and does not indicate their specialty, which has its downside exactly in culture and patterns of behavior. The study analyzed how the traditional culture is important in the lives of Roma and how the social system treats this ethnic minority. Being a Rom in its original sense means to be human and to be equal with everyone, but paradoxically it is expected that non-Roma nation sets free of stereotypes and prejudices and to contribute to the integration and acceptance of Roma in our social system.

(C) 2017 IJCRSEE. All rights reserved.

\section{INTRODUCTION}

If Roma have their own cultural patterns that are in many ways different from the cultural patterns of the majority of the population with whom they live, whether that necessarily implies that we must marginalize? The study presents a case study conceived through the analysis of the Roma minority and their integration into social, social, cultural and educational context of the area where they live. The first part of the research deals with the origin of Roma, while the second and third chapters focus on the social integration of Roma in the social and educational system. Social deprivation Roma is not characteristic only for Serbia but also for other countries in the world, and every form of discrimination involves concerns. Often referred as two key reasons of social deprivation Roma are: low education

Corresponding Author

Dr. Jelena Maksimović, University of Niš, Faculty of Philosophy, E-mail: jelena.maksimovic@filfak.ni.ac.rs

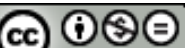

This work is licensed under a Creative Commons Attribution - NonCommercial - NoDerivs 4.0. The article is published with Open Access at www.ijcrsee.com levels and low levels of expertise. And when we talk about discrimination and integration of Roma, it is necessary to bear in mind that they are most often exposed to negative discrimination. In addition to the objective picture of the living conditions according to which Roma are highly deprived social group (unbearably poor housing conditions, high unemployment of working-age population, insufficient involvement of children in the education system, poor communication with the majority population, poor hygiene and health situation), an important part of the complete picture about their life represents a subjective image of people.

The question is how much the situation has now changed from the generalization of stereotypes that are still present. The paper analyzes certain surveys which examined social distance towards members of the Roma. Roma Integration Strategies should experience a much higher recognition than the one on paper that confirms the legitimate and equal rights of ethnic minorities with the rest of the world (Đurić, 1987; Jakšić, 2002: 335-355; Mirga, Georgi, 2004 11-49).

The method of theoretical analysis shows the characteristics of the origin, cus- 
toms, and culture of Roma, and then examines several documents to affirm the rights of Roma nationality, as well as the results of surveys on the status of the Roma nationality. All the research, but also practice suggests that the success of the two contact groups depends on them working together, finding similarities, as well as finding and accepting cultural forms from other groups.

\section{CASE STUDY - CULTURAL ROMA PATTERN}

Roma are assigned different names (Gypsy, Gitanos). Members of this nation refer to each other as Roma, which in essence means to be human, while one of the premise is that Roma are named after Rama, hero of the Indian epic Ramayana, the second assumption is about the legend that the Roma arrived in Europe as Roma children i.e. Chavo Roma (Đurić, 1987). There is no systematized written historical sources on the origin of the Roma and their history, but is based on oral tradition, transgenerational transmission, and informed that the Roma originate from India. This is supported by the Roma language in which there are preserved traces of their Indian origin. During all their migrations Roma were exposed to assimilation, which is partly the result of attempts by the authorities in the countries inhabited by Rome to keep them in one place, and partly the result of their fear of persecution and discrimination, and the Roma themselves denied their ethnicity. This process of assimilation of Roma lasts up to the present day. This is the reason why Roma today do not have very clear and unique national and cultural characteristics. For example, although they have their own language, Roma in different countries speak different dialects or language which is a mixture of the Romani language and the environment in which they live. Also, customs, religion and other elements of Roma culture is different in Roma who live in different regions. For centuries, Roma people kept their own cultural identity from disappearing with so-called proper nurturing of Roma holidays (Vlasuljica, St. George, Bibi). Vasilica and St. George ("Erdelez") are above religious, multi-day, unique holidays of all Roma people. Marriage traditions have always been the wealthiest ceremonies in Roma life cycle, followed by several days of gathering of relatives, friends and acquaintances. By implementing even weekly, established actions pictured the position of women and men, the economic power of the family, complex family relationships and others. Establishment of marriage is followed by a series of magical rites of happiness, prosperity, harmony and maximizing offspring between spouses. Communication on Romani language is kept within the family and possibly with neighbors and friends. Older age groups, families with many children and residents of the city are the greatest experts in native language. In the battle against forgetting their origins the most important step is the respect of the Romani language among the Roma (Čvorović, 2006: 47-59; Vantić-Tanjić, 2008; Saitović, 2014).

Roma are almost always immersed in another culture, they are characterized by constant adjustment, assimilation, but also important differences in religion and language. Native language is a distinctive sign of the national identity. But until today, the Roma have preserved a lot of cultural elements that certainly testify to their ethnic identity, including language and beliefs, customs, habits, norms, laws, and many other properties.

\section{CASE STUDY - SOCIAL INTEGRATION OF ROMA INTO THE SOCIAL SYSTEM}

On the whole, the number and proportion of Roma in the total population of Serbia shows significant variations caused by demographic factors, but also the constant changes in the declaration of ethnicity, which is characteristic of this ethnic community. The reasons should be sought through the process of assimilation or ethnic mimicry Roma due to discrimination, segregation, marginalization and many other reasons (Horvat, 2008: 443472).

The demographic development of the Roma is characterized by negative tendencies, especially when it comes to the educational structure, employment, housing and health care. Nationality, as the most important ethnic determinant, was incorporated into the content of all population censuses after the Second World War. We must bear in mind that every census represented a mirror of current social and political situation. In the early 1990s, Roma political movements and non-governmental organizations are becoming more active in addressing the problems of Roma (Raduški, 2013; Raduški, 2009: 189202; Raduški 2004: 433-445).

When we talk about social inclusion of Roma we should rely on ethnicity because 
the opposite can cause misunderstandings, disagreements and suspicion. Roma distrust towards some suggestions, ideas, projects and attitudes is conditioned by the historical experiences with many dirty tricks, manipulations and abuses. On the other hand, it is not easy to determine the meaning of the concept of social inclusion, although it is widely present in everyday speech, communication and literature. The question is: How to ensure social inclusion of Roma in the local and wider community and at the same time preserve their cultural, linguistic, and other conventional characteristics, which are not only part of their tradition, self-identification but also the persistence as specific national minority. There is no widely accepted nor the consistent definition of the concept of social inclusion, although the term is often used when it comes to the marginalized, minority and socially risky and deprived social groups. Most of the studies, texts or debates on social exclusion was built on the philosophical and theoretical, legal and exploratory foundations of concepts of universal human rights, and in the literature is mainly in negative context, and concepts such as social exclusion, marginalization, discrimination, rather than it's presented in positive manner (Đorđević, Filipović 2004: 201-204; Jakšić, 2002: 335- 355; Jugović, 2007).

Social exclusion means such position of individuals or small or large social groups that are thwarted in their educational and cultural elevation. Spiritual values and civilization achievements are unavailable to them. They are excluded from the common ordinary, religious, and cultural life activities of narrower or wider community. Therefore, they are forced to cultivate specific lifestyle, customs, habits, forms of communication and behavior or living within the framework of sub-cultural system, often in conflict with the dominating culture and value system. From the psychological aspect the social inclusion means such social conditions in which people can develop and express as free self aware personalities that come together and communicate with other people freely and of their own choice, developing all their physical, mental and creative potentials without jeopardizing others. From the psychological point of view, too, social inclusion contains a special feeling of connection and belonging to certain social groups, communities and global society, love for other people, for people of their own kind, and people in general (Vasović, 1997). The question is whether one can talk about a special Roma culture or subculture. Bearing in mind the traditions, their customs, language, music, games, a common history and destiny could be concluded that there is a specific Roma culture. On the other hand, if we take into account the historically known fact of often mass migrations of Roma, influences of other cultures of the majority countries on whose territory they lived, inevitably customization of Roma to the requirements of majority communities and other conditions of their lives, as well as the visible religious, customary and cultural differences, then the previous conclusion can be questioned. With this arguments it can be added the fact of the lack of a single Roma language, but rather dialects, which differ from each other. The educational structure and educational status of any social group significantly affects the possibility of performing a variety of social roles, working and economic, political and social. These personal or group characteristics affect the possibilities of social promotion, as well as lifestyles, social interactions and relationships and engaging in various forms of social life in the community (Milosavljević, 1993: 34- 47).

With social distance towards the Roma, majority population loses a lot of valuable experience, more than we could possibly have guessed. Part of their national identity that must be preserved and which is their tradition are: customs, cheerful nature, the richness of language, oral traditions, musicality, propensity to jokes, optimism, wisdom, survival, life experience beyond chronological age etc. (Vantić-Tanjić 2008; Saitović, 2014). These are just some of the characteristics of their own ethnic group which should be preserved as the basis for integration - inclusion. Inclusion would enable them to preserve their identity, and at the same time accept the contemporary requirements of the new millennium in terms of education and employment. This process reduces or completely suppresses social distance towards the Roma, which lasts long and is inappropriate for human relations.

On the other hand, the early inclusion of Roma children in kindergarten is an important step in combating social distance and prejudice against Roma. At an early age increased social interaction helps children to develop friendship which certainly can positively be reflected on the motivation and progression in learning. From the quality of social relations in kindergarten children, teachers, families and community members have benefits. They represent the foundation for future good relations among adults, for developing tolerance, prosociality, empathy and altruism (Kojić, 


\section{3: 79-87).}

Always immersed in another culture, Roma life is characterized by constant adjustment and acceptance of changes in the environment. This inevitably led to further disagreements in the culture, customs and language. The term Romani "nation" has more symbolic, moral and political rather than legal value. In fact, the Roma as citizens of certain countries are clearly a minority. It is therefore important for them to be treated within the law, that they be guaranteed basic rights and freedoms as to all other citizens, or to be treated as other minorities that have the right to protect their rights (Mirga, Georgi 2004: 11- 49).

Finally, it should be noted that the emancipation of the Roma in the socio-cultural and socio-psychological sense is not possible without the liberation of Roma from "their own prejudice", a non-Roma population from prejudice and from doubts about human qualities of Romani people.

\section{CASE STUDY - INTEGRATION OF ROMA INTO THE EDUCATION SYSTEM}

Education is most closely associated with socialization and upbringing. Socialization represents the widest process of introducing young human being in social life through various forms of learning. Education is a narrow part of a broader process of social learning in all societies and cultures which has a decisive significance. The educational status of Roma across Europe is considerably lower than the status of the population. Low educational level, on the one hand, is an obstacle to employment and ensuring the existence and the conditions for development and progress, but also leads to deepening poverty. On the other hand, poverty is certainly an obstacle for the education of children. Thus, the Roma population "for decades revolves in a vicious circle" from which it cannot come out alone. Education is the key to moving out of poverty, measures that will contribute to improving the situation of Roma have to be taken, starting with the facts and analysis of the reasons that contribute to this state of affairs (Đigić, 2007: 4). The low level of education of Roma reflects adversely on their professional structure. Most of the Roma are poor and without permanent employment, since they are uneducated and unskilled, but cannot compete in the labor market. Jobs that they can work are underpaid, unappreciated and seasonal. Many
Roma are beneficiaries of social aid, which, even when regularly received, is not sufficient for basic needs (Horvat, 2008: 443-472; Jakšić, 2002: 333-335; Macura-Milovanović, 2010; Raduški, 2009: 189- 202).

Most Roma live in segregated neighborhoods that are unsanitary, often without electricity, water, located in marginalized areas of the city, on dumps and under bridges. Life in these conditions is very difficult for poor families that are unable to provide basic living conditions for many of its members, the children were not vaccinated, health care is poor, a life expectancy of Roma is significantly lower than other populations. The Roma population is the largest ethnic group that is not sufficiently present in education. Roma have a low percentage of school enrollments, low completion level of the class, even in the first four grades of elementary school, a high percentage of repetition, dropouts and very low level of continuing education in secondary schools (Macura-Milovanović, 2010).

Literacy as a basic feature of the educational structure of the population makes the elementary assumption of education process and is a good indicator of social, economic and cultural development of a social environment. In countries where illiteracy is eradicated, the issue of literacy is not covered by the census, while in our country was incorporated into the content of the current records. Serbia, unfortunately, is one of those European countries which have not yet eradicated elementary illiteracy at the beginning of the XXI century. According to the data, in Serbia there are 230 thousand illiterate persons, which is $3.4 \%$ of the total population older than 10 (Raduški 2004: 433-445). What we conclude this case study is that of the Roma in the education system in Serbia there are no reliable written records. Some of the main reasons for the lack of valid data can be lack of personal documents or registration of Roma, the mobility of many families that are looking for seasonal jobs and many other reasons. Exclusion of Romani children from the education system is a problem of enormous proportions that exists in all European societies where Romani population lives. Factors of such conditions include racism of non-Roma parents, which are opposed to the entry of Roma children in schools, discriminatory practices by educational authorities and bureaucratic procedure for enrollment in school and Roma poverty that prevents the funding of education, social and physical isolation of Roma from the society, living in segregated and ghettoized neighborhoods distant 
from schools (Macura-Milovanović, 2010: 3). Education of Roma children is one of the most important issues in efforts to improve living conditions and changing socio-economic situation of Roma. As Roma syndrome irregularly going to a school and early school leaving is still present. Some think that the possibility of instruction in the Roma native language would greatly facilitate their further education, before it cause furthers discrimination, while on the other hand it is pointed out that the language barrier is not the only obstacle to regular education, but also poor financial situation of the family, education level of parents, traditions, customs and more.

For Roma who had subordinated their whole life to mere survival, children's education has no special value. Locked in their own ethnic frames, semi-literate and uneducated, they cannot help their children to achieve better success in school or in their professional advancement. In addition, there is a lack of commitment and motivation of the teaching staff for special work with Roma children, as well as accepting and misunderstanding specific life style of Roma by the wider community (Raduški, 2009: 189-202).

Inclusion of Roma into the education system and ensuring continuity of education is the first step towards improving education for Roma. With the increasing number of Roma children, youth and adults involved in the education system, Roma can have the same rate of progression through the levels of the system, as well as non-Roma children (The draft Strategy for Improving Education of Roma in Serbia, 2003: 11).

The aim of involving Roma into the education system and ensuring continuity in education the following task are defined:

1. Creation of system requirements for inclusion of Roma into the education system. Creating a body that will be responsible for the realization of this objective. Their function is reflected in the implementation of certain activities that have to contribute to the institutional inclusion of Roma and / or coordinating the work of others who participate in the process.

2. Developing a specific enrollment policy for Roma children and young people. If they do not attend preschool, Roma children until the beginning of schooling live in a culture that is significantly different from the majority, and these differences must be respected within the manner and criteria enrollment of Roma children in school, also later, at the level of secondary and higher education. The enroll- ment policy must pave the way for the educational system, to eliminate the differences that are the result of educational deprivation, that should not be deepened and create conditions for discrimination.

3. Preparation of educational institutions for inclusion of Roma in education. The bearers of main activities will be the local community and educational institutions. The Ministry of Education will support this process at the level of selection and implementation of different solutions to the problem of inclusion of Romani children, coordinating activities in certain institutions, and by providing additional funds for the costs of preparation and implementation of programs and didactic equipment of the institutions.

4. Preparation of Roma children for school. This includes work on the system preparation of Roma preschoolers in order to meet the demands presented by the school, and that in the future meet the standard criteria for readiness for school. It is especially important to ensure continuity in schooling. A child who is not prepared to enter the school system is hardly to be adapted and rapidly drops out of it. Preparing Roma children for school also means working with parents, from whose motivation largely depends whether the child will be enrolled in school and attend classes regularly.

5. Financial support to the Roma in education. Low socio-economic status of the Roma population is almost always on the list of factors that create obstacles to the inclusion of Roma into the education system, particularly in ensuring continuity in their education. Providing financial support to Roma in education must ensure elementary conditions that requires regular education and to flexibly follow the needs of the different levels of education.

Above mentioned five proposals certainly can enhance the educational integration of Roma, and therefore social integration of Roma in the social system, as extremely unfavorable educational structure of Roma is one of the most important cause of their disintegratedness into society, but also affects the maintenance and deepening of socio-economic and cultural gap between Roma and the rest of the population. The basic requirement for improving the socio-economic and cultural status of the Roma, and social mobility and integration into society is education. This is also the objective of case study of the Roma national minority.

Low educational level, on the one hand, 
is an obstacle to employment and ensuring the existence and the conditions for development and progress, and so leads to deepening poverty. On the other hand, poverty is certainly an obstacle for the education of children. Considering that education is the key to moving out of poverty, measures that will contribute to improving the situation of Roma have to be taken. Exclusion of Roma children from the education system is a problem of enormous proportions, which will result in the generation that will continue to be illiterate and thus socially maladjusted. Therefore, the issue of Roma inclusion in the education system is one of the most current issues, especially from the standpoint of social integration, social mobility, improving of the socio-economic status and national emancipation. Inclusion of Roma into the education system and ensuring continuity of education is the first step towards improving education for Roma. With the increasing number of Roma children, young people and adults involved in the education system, Roma can be covered by an equal education system and have the same rate of progression through the levels of the system, as well as non-Roma children.

It is also important to note that low levels of parental education, which often goes hand in hand with poverty, is a source of additional negative impact on the educational achievement of a child. The level of education of parents significantly acts on the set of parental behaviors that can be linked to education and the educational achievement of children. The education level of parents is a significant predictor of parental involvement in children's education and parental expectations. Parents who have attained higher levels of education have higher expectations of their children in terms of their educational attainment. They are in a significantly greater extent involved in the education of their children and help them in mastering the curriculum. In fact, research suggests that active and supportive parenting behaviors are especially important for academic achievement of children in the first years of their formal education. The question is whether the socio-economic depression represents a unique source of differences in valuation and vision of the school, the perception of education, aspirations, attitudes and general life values of parents whose children attend the school? Are there differences that can be attributed to cultural factors and attitudes that members of a particular ethnic, ie. Roma community foster? In an effort to provide answers to these questions, a survey was carried out in order to identify attitudes towards education, aspirations and values of parents - Roma and non-Roma parents of different socio-economic status whose children attend the school. The practical significance of this research is related to the identification of specific parental attitudes that can have a disturbing influence on the adaptation of children to school and their potential educational attainment (Tovilović, Novović, Biro, 2009: 332-354). This publication is for wide-ranging audience - all those who believe or want to believe in the concept of education for all and equal opportunities in education for all children, regardless of their origin, and the current position in society. Its aim is to present one of the current problems of society through a unique case study, which sees the resolution of the problem in providing support to children in education, especially children from vulnerable social groups, such as Roma children. Children from the Roma community belong to one of the most vulnerable groups in contemporary society in Serbia, living on the margins, with little chance for success and achieving their rights and their dreams. As a democratic society, we want to change that.

\section{ADVANTAGES AND DISADVANTAGES OF CASE STUDY IN THE STUDY OF THE ROMA MINORITY}

Case studies include intensive study of a particular unit or system which has the characteristics of the entity, which is exactly the case with the ethnic group we observed. They allow plunge into the depths of the studied " case " and understanding of what lies behind the phenomenal, in the work we have done our best to present the rich descriptions of social and educational processes and phenomena, one example is the analysis of a single ethnic minorities such as the Roma. To case study become a scientific research, it must be strictly and rigorously conducted by scientific theory and should be systematic and critical, what we have in this study acknowledged relying on numerous sources that allow analyzing the characteristics of the Roma, their cultural identity, traditions, problems integration of Roma into the education system, the problem of integration of Roma in the social system. To point out the reasons for the use of case study in this research we will present different 
sources of author Shulman of the case study (Shulman, 1991: 393-396):

(1) "Case" materials. These are the data of which is case study made, such as diaries, videos, student assignments, etc. These data can be collected and organized by teachers themselves, or other persons.

(2) "Case" reports. The reports gathered experience and interpretation at "the first hand". Their own teachers create and write them.

(3) "Case" research. This is about a specific technique of qualitative research that is close to anthropological studies. Usually organized by third parties interested in a certain pedagogical problem.

(4) "Case" teaching. They contain a variety of original sources, narrative notes, teaching time, interviews with teachers etc. In terms of volume, they vary from short to very extensive views.

(5) "Case" teaching strategies. Here is a case study of an independent teaching method used at all previously mentioned materials. As a teaching strategy, case study varies from Socratic dialogue professors and students to autodidactic case study (in which the student is guided by comments or computer program).

(6) "Case" manuals. Manuals are collections of paradigmatic case studies that represent a certain problem, a theme. This can be a collection of student learning, school discipline, curriculum, physical organization of the classroom etc.

(7) "Case" programs. The programs are the youngest category of case studies. Teaching and scientific power organized around representative case studies is presented in them.

Video recordings of different educational situations, teaching, learning, counseling are sometimes called case study. The case study describes a real problem situation and in its potential to offer not only the reactions and behavior, but also strategy, dispositions, habits of thought. The case study presents an authentic narration that illustrates a general principle, an idea, a theory.

A case study is used when the investigator has little control over events and when it comes to real problems placed in the context of a specific environment. Unlike specific targeting methods, case study addresses issues that may require a comprehensive understanding of events by using inductive logic. Before you start designing case study it is necessary to determine and select the type of case study that will be used during the research. Types of case study: describing (mainly used one or two cases an event to display the status. Describing case study is used to gain an understanding of the unknown status of a particular case), explanatory or pilot (explanatory case study is conducted prior to the implementation of large research. Its basic function is to assist in the identification of key issues and types of assessment before you start real research. The biggest lack of this type of case study is that its outputs can be so convincing that based on them premature conclusion can be brought), cumulative (cumulative case study is used to gather information from different sources and in different periods. The idea is to collect already made studies, and later do classification of conclusions, which in the end leads to generalization of final conclusion and avoiding repetition of completed studies), and critical (critical case study examines one or more cases to investigate situations that are of little importance, or more generally, do not have any, and to challenge the generally accepted assumption).

As the case study is carried out in very different areas, it is almost impossible to determine specific or universal method or manner of implementation or the design of case study. Jin (Yin, 1994) wrote about the case study and suggested techniques for successful organization and conducting the research. They proposed six steps that should be used: (1) choice of single or multiple modal approach (2) selection of participants (3) data collection (4) data analysis (5) preparing a report (6) questioning the value and reliability. These authors also emphasize the importance of clear articulation of a theoretical perspective, determining the aims of case study, case selection, selection of appropriate methods of data collection, as well as allowing certain compromises during the formation of the final report. A choice of single or multiple modal approach is used to obtain a complete picture of the case study participants, and researchers can use a variety of methods. Common methods include interviews, protocol analysis, field studies, and observations of the participants. Case studies can be used by one participant or a small group of participants.

Why did we put special emphasis on the characteristics of case study? Analysis of the cultural identity of the Roma minority, the advantages and disadvantages of integration of the Roma minority in the social system was based on very specific and individual (case) material, based on written (case) report, then (case) studies that have been conducted, and strategy proposal of improvement of the edu- 
cation of Roma who are here methodologically classified as (case) program, which should not be left out when it comes to the integration of Roma into the social system. Case studies, as already stated, we use in specific cases, when the investigator has little (or none) control when it comes to issues of specific environment. Therefore, the emphasis in this study is on very specific subject of research (Roma national minority), the sample and the selection of study participants (members of the Roma minority), data analysis (written documents about the Roma population), evaluation of the value of research (theoretical and empirical contributions to status of Roma in the social system of the Republic of Serbia).

Now it's quite clear why is Case Study method selected, because it is a completely separate ethno-cultural subject of research, and that is the Roma minority, which should and must be integrated into our democratic society with the absence of any prejudice or steorotip.

\section{CONCLUDING REMARKS}

The historical experience of different groups has prompted a huge variety of cultural and social characteristics. The feeling of closeness and community of Roma and nonRoma nation exists, but it is evidently threatened by hostility that is often manifested by non-Roma society.

The appeal is to accept the concept of multi-ethnicity and multiculturalism which would allow different ethnic communities to preserve their own national identity, ethnic, religious and cultural characteristics without precluding the possibility of adapting their successful integration into society itself.

Researchers are studying the input data using many interpretations to find a connection between the subjects of research. Used multiple methods of data collection and a number of techniques of their analysis give researchers the ability to triangulate information in order to support the results and conclusions of the research. Appropriate case study reports on the collected data so that complex issues are transformed into easily understandable allowing the reader to wonder and explore study and thus to come to an independent conclusion. Researchers pay special attention to emphasizing sufficient evidence. Once the key variables are identified, they can be analyzed. At this stage of case study, reliability plays a key role, many researchers go a long way to ensure the reliability and value of their interpretation of the collected data. It is important to repeat that the case study is scientific method that has its own laws and rules.

\section{ACKNOWLEDGMENTS}

The article is the result of the project 'Pedagogical pluralism as the basis of educational strategies' No 179036 (2011-2014), whose implementation is funded by the Ministry of Science and Technological Development of the Republic of Serbia.

\section{Conflict of interests}

Authors declare no conflict of interest.

\section{REFERENCES}

Čvorović, J. (2006). The making of the Gypses: Invention of traditions. Etnoantropološki problem, 47-59.

Đigić (2007). Položaj roma- Problemi i prespektive [The situation of the Roma - Problems and Prospects]. Beograd: Magistarski rad odbranjen na odeljenju za psihologiju.

Đurić, R. (1987). Seobe Roma [Migration of Roma]. Beograd: BIGZ

Đorđević, D. i Filipović, M. (2004). Romi i etnokulturna pravda: ka modelu integracije. Društvene promene, kulturni i etički odnosi i evrointegracijski procesi na Balkanu [Roma ethno-cultural justice: towards a model of integration. Social changes, cultural and ethical concerns and evrointegracijski processes in the Balkans]: Niš: Filozofski fakultet, 201-204.

Horvat, A. (2008). Segregacijom do integracije, Mogućnosti integrisanog obrazovanja Roma [Segregation to integration, The possibilities of integrated education of Roma]. Zbornik radova pravnog fakulteta u Splitu, 46 (2), 443-472

Jakšić, B. (2002). Romi između diskriminacije i integracije. Društvene promene i položaj Roma [Roma between discrimination and integration. Social changes and the position of Roma]. Filozofija i društvo, XIX-XX, 333-355

Jugović, A. (2007). Izvan granica društva: Marginalizacija, socijalna isključenost i marginalne grupe [Beyond the borders of society: marginalization, social exclusion and marginal groups]. Beograd: Socijalna misao, 53

Kojić, M. (2013). Romska deca u vrtiću-korak u suzbijanju socijalne distance prema Romima [Roma children in kindergarten-step in combating social distance towards Roma]. Socijalna misao, 2, 79-87.

Macura-Milovanović, S. (2010). Specifični problemi u obrazovanju romske dece [Specific problems in education of Roma children]. Uzdanica, 5(2), Jagodina: Pedagoški fakultet.

Milosavljević, M. (1993). Romi i devijacije (Roma and Deviance), $u$ : Društvene promene i položaj Roma, SANU - Institut za socijalnu politiku, 
Beograd, 34-47.

Mirga, A. i Georgi, N. (2004). Romi u XXI veku. U Romi - od zaboravljene manjine do manjine u usponu [Roma in the XXI century. In Roma - from a forgotten minority to minority on the rise], 11-41. Niš: Odbor za građansku inicijativu.

Predlog strategije unapređivanja obrazovanja Roma u Republici Srbiji [The draft Strategy for Improving Education of Roma in Serbia, 2003] (2003). Beograd: Ministarstvo prosvete i sporta Republike Srbije.

Raduški, N. (2004). Romska nacionalna manjina u Srbiji- demografske tendencije i problem [The Roma minority in Serbia- demographic trends and problems]. Migracijske $i$ etničke teme, 20 (4), 433-445. http://hrcak.srce.hr/7063

Raduški, N. (2009). Obrazovanje kao ključ za integraciju Roma u društvo [Education as the key to the integration of Roma into society]. Politicka revija, 19(1), 189-205.

Raduški, N. (2013). Romi na etnografskoj karti Srbije. Primeri dobre prakse integracij roma u lokalnim samoupravama [Roma in Serbia ethnographic map. Good practice examples of integration of Roma in local governments]. Beograd: Zaštitnik građana.

Saitović, B. (2014). Kulturni identitet Roma topličnog kraja [Cultural identity roma of Toplica region]. Beograd: Romineterpress.

Shulman, L. S. (1991). Ways of seeing, ways of knowing: Ways of teaching, ways of learning about teaching. Journal of Curriculum Studies, 23(5), 393-395. http://dx.doi org/10.1080/0022027910230501

Tovilović, S., Novović, Z., \& Biro, M. (2009). Stavovi prema obrazovanju, aspiracije i vrednosti romskih i neromskih roditelja čija deca polaze $u$ školu [Attitudes towards education, aspirations and values of Roma and non-Roma parents whose children start school]. Pedagoška stvarnost, 55, 332-354.

Vantić-Tanjić, M. (2008). Istorija, kultra $i$ tradicija Roma [History The culture and traditions of Roma]. Tuzla: BOSPO i udruženje Bosanski savjet za pomoć

Vasović, M. (1997). Karakteristike grupnih identifikacija $i$ odnosa prema etničkim grupama Između osporavanja i podrške [Characteristics of group identification and attitudes towards ethnic groups, between challenge and support]. Beograd: Centar za politikološka istraživanja i javno mnjenje, Institut društvenih nauka, Fridrih Ebert Stiftung.

Yin, R. K. (1994). Case study research: Design and methods (2nd ed.). Newbury Park, CA: Sage Publications. 